\title{
Roth spots in acute myeloid leukaemia
}

\author{
Atanu Chandra (i) , ${ }^{1}$ Uddalak Chakraborty, ${ }^{1}$ Saikot Ganai, ${ }^{2}$ Aritra Kumar Ray ${ }^{1}$
}

${ }^{1}$ Department of Internal Medicine, RG Kar Medical College, Kolkata, India ${ }^{2}$ Department of Medicine, Midnapore Medical College and Hospital, Midnapore, India

\section{Correspondence to} Dr Atanu Chandra; chandraatanu123@gmail.com

Accepted 31 July 2020
D Check for updates

(c) BMJ Publishing Group Limited 2020. No commercial re-use. See rights and permissions. Published by BMJ.

\begin{tabular}{l}
\hline To cite: Chandra A, \\
Chakraborty U, Ganai S, \\
et al. BMJ Case Rep \\
2020;13:e238133. \\
doi:10.1136/bcr-2020- \\
238133 \\
\hline
\end{tabular}

\section{DESCRIPTION}

A 28-year-old woman without any comorbidity presented to us with a history of low-grade intermittent fever and generalised weakness for 3 weeks. On further enquiry, she also admitted to have night sweats during the same period. She also presented with transient floaters in both her eyes for about 10 days prior to her admission. She neither had any skin rashes, joint pain, cough or bleeding manifestations nor any history of tuberculosis in the past, or any such recent contact. On examination, temperature was mildly raised $\left(38.1^{\circ} \mathrm{C}\right)$ with stable vitals. She was moderately pale without any lymphadenopathy or sternal tenderness. There was no evidence of cutaneous or mucosal bleeding. Spleen was palpable $1 \mathrm{~cm}$ below the left lower costal margin. Other systems examinations were within normal limits. As she had some visual problems, a referral to the department of ophthalmology and a subsequent direct ophthalmoscopy revealed multiple haemorrhages with pale centre scattered throughout the retinas of both eyes suggestive of Roth spots along with dilated and tortuous retinal veins (yellow arrow) (figure 1).

Complete blood count revealed haemoglobin of $66 \mathrm{~g} / \mathrm{L}$, white blood cells (WBC) count of $110 \times 10^{9} / \mathrm{L}$ and thrombocytopenia (platelet count of $40.6 \times 10^{9} / \mathrm{L}$ ). Peripheral blood smears showed predominant population of myeloblasts $(72 \%$ of the total WBC count) with prominent nucleoli and heterochromatic nucleus (figure 2). Serum lactate dehydrogenase was elevated $(954 \mathrm{U} / \mathrm{L}$, normal
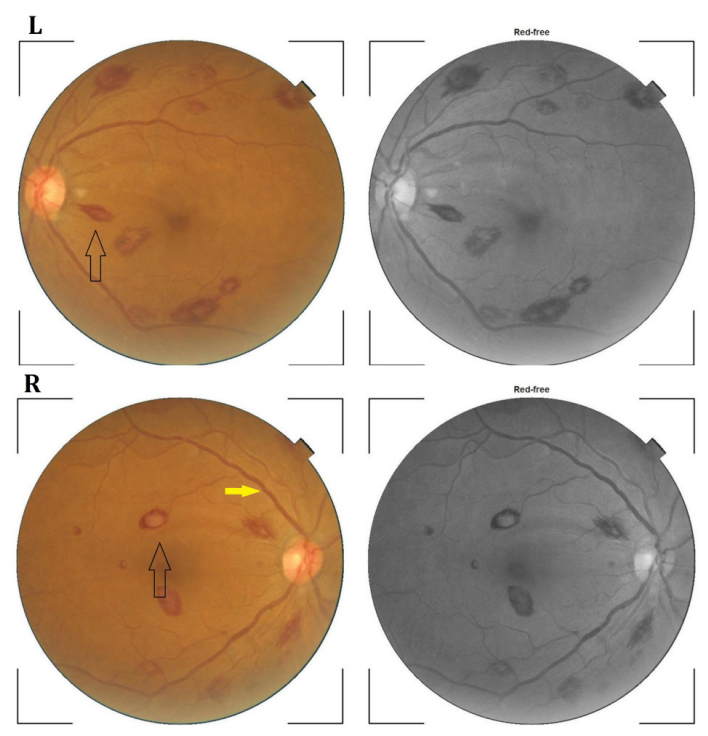

Figure 1 Fundoscopy of both eyes showing multiple retinal haemorrhages with pale centre, Roth spots (solid arrows) and dilated retinal vein with mild tortuosity (yellow arrow).

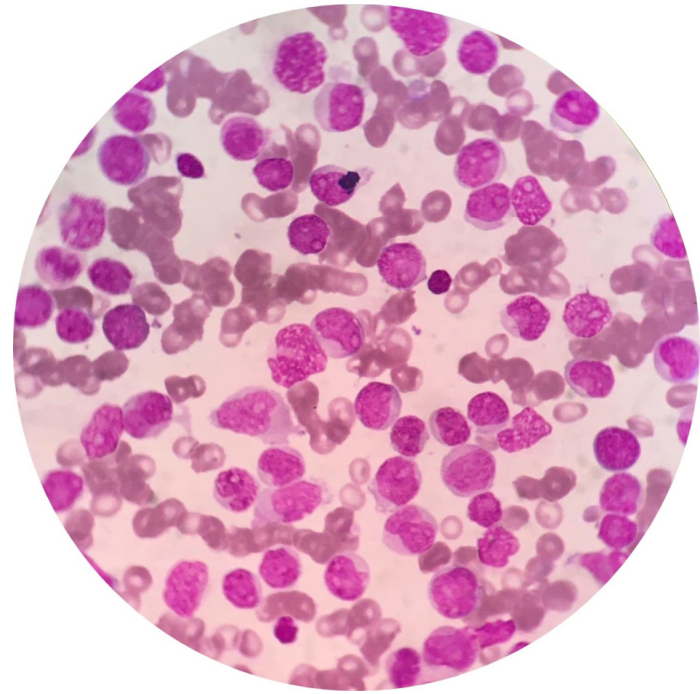

Figure 2 Peripheral blood smear with plenty of blast cells with prominent nucleoli and heterochromatic nucleus.

$<248 \mathrm{U} / \mathrm{L})$. Other laboratory parameters like liver function tests, renal function tests and serum uric acid were within reference range. Blood culture for both aerobic and anaerobic organism showed no growth. Transoesophageal echocardiography did not reveal any vegetation. Immunophenotyping study of peripheral blood showed CD15, CD33 and Human leukocyte antigen-DR isotype (HLA-DR) positivity with CD14 negative pattern. The blasts were positive for myeloperoxidase but negative for periodic acid-Schiff. This immunophenotyping and cytochemical staining pattern confirmed the diagnosis of acute myeloid leukaemia M2 variant. The patient was then referred to the department of hemato-oncology for further evaluation and management.

Ocular manifestations in leukaemia are either due to direct infiltration of leukemic cells into the orbit and the globe, including optic nerve, choroid and retina, or ophthalmic signs secondary to central nervous system involvement (papilloedema and cranial nerve involvement) or retinal vascular abnormalities (such as retinal haemorrhages, cotton-wool spots, vitreous haemorrhages and 'sausage link' engorgement of retinal veins). ${ }^{12}$ The retinal vascular abnormalities are mainly related to anaemia, thrombocytopenia, infiltration of leukemic cells and hyperviscosity syndrome. Retinal haemorrhages are the most striking feature of acute leukaemia. Retinal haemorrhages may manifest as dot and blot, flame-shaped or white-centred, haemorrhages. ${ }^{3}$ Moritz Roth, a Swiss physician, first described white-centred retinal haemorrhages in 1872, which was later named after him. Roth 
spots have been traditionally believed to be pathognomonic of subacute bacterial endocarditis. But it has also been described in other conditions like toxoplasmosis, HIV, leukaemia, diabetic retinopathy, hypertensive retinopathy, vasculitis, neonatal birth trauma and non-accidental trauma or abusive head trauma in children. ${ }^{4}$ The exact pathogenesis is unknown, but the proposed mechanism may be attributed to rupture of retinal blood vessels followed by platelets and fibrin aggregation. ${ }^{34}$ The white centres of Roth spots in acute leukaemia mainly represent accumulation of leukemic cells.

Roth spots without any other ocular manifestations like preretinal or vitreous haemorrhages, or systemic bleeding manifestations have been rarely reported in literature. ${ }^{5}$ We seek to acquaint clinicians with this ocular sign and highlight the importance of thorough history taking, careful physical examination and relevant investigations to detect an underlying systemic disease.

\section{Patient's perspective}

I am overwhelmed by the care I received from my doctors. I know I have blood cancer. I know my days are numbered, but the compassion and care I received here were beyond my expectations.

\section{Learning points}

Roth spots are not pathognomonic for infective endocarditis as previously thought and in fact they are seen as a nonspecific sign in various conditions like toxoplasmosis, HIV, leukaemia, diabetic retinopathy, hypertensive retinopathy and vasculitis.

- Clinicians should be acquainted with the common underlying systemic diseases associated with this ocular sign.
Contributors AC: conception and design of the work, acquisition of data, drafting the work, revising the work critically for important intellectual content, final approval of the version to be published and agree to be accountable for all aspects of the work in ensuring that questions related to the accuracy or integrity of any part of the work are appropriately investigated and resolved. UC: acquisition, analysis and interpretation of data, drafting the work, final approval of the version to be published and agree to be accountable for all aspects of the work in ensuring that questions related to the accuracy or integrity of any part of the work are appropriately investigated and resolved. SG: conception of the work, drafting the work, revising the work critically for important intellectual content, final approval of the version to be published and agree to be accountable for all aspects of the work in ensuring that questions related to the accuracy or integrity of any part of the work are appropriately investigated and resolved. AKR: design of the work, revising the work critically for important intellectual content, final approval of the version to be published and agree to be accountable for all aspects of the work in ensuring that questions related to the accuracy or integrity of any part of the work are appropriately investigated and resolved.

Funding The authors have not declared a specific grant for this research from any funding agency in the public, commercial or not-for-profit sectors.

Competing interests None declared.

Patient consent for publication Obtained.

Provenance and peer review Not commissioned; externally peer reviewed.

\section{ORCID iD}

Atanu Chandra http://orcid.org/0000-0002-3809-8926

\section{REFERENCES}

1 Reddy SC, Jackson N. Retinopathy in acute leukaemia at initial diagnosis: correlation of fundus lesions and haematological parameters. Acta Ophthalmol Scand 2004;82:81-5.

2 Perez Rogers A, Estes M. Hyperviscosity Syndrome. [Updated 2020 Apr 27]. In: StatPearls [Internet]. Treasure Island (FL): StatPearls Publishing, 2020. https://www. ncbi.nlm.nih.gov/books/NBK518963/

3 abu el-Asrar AM, al-Momen AK, Kangave D, et al. Correlation of fundus lesions and hematologic findings in leukemic retinopathy. Eur J Ophthalmol 1996;6:167-72.

4 Ling R, James B. White-centred retinal haemorrhages (Roth spots). Postgrad Med J 1998;74:581-2.

5 Chakraborty PP, Mandal SK, Bandyopadhyay D, et al. Roth's spots as an only sign of acute myeloid leukemia. J Assoc Physicians India 2006;54:547.

Copyright 2020 BMJ Publishing Group. All rights reserved. For permission to reuse any of this content visit

https://www.bmj.com/company/products-services/rights-and-licensing/permissions/

BMJ Case Report Fellows may re-use this article for personal use and teaching without any further permission.

Become a Fellow of BMJ Case Reports today and you can:

- Submit as many cases as you like

- Enjoy fast sympathetic peer review and rapid publication of accepted articles

- Access all the published articles

Re-use any of the published material for personal use and teaching without further permission

Customer Service

If you have any further queries about your subscription, please contact our customer services team on +44 (0) 2071111105 or via email at support@bmj.com.

Visit casereports.bmj.com for more articles like this and to become a Fellow 